\title{
Ambient Air Quality Assessment of Al-Mansoriah Residential Area in the State of Kuwait
}

\author{
S.M. Al-Salem*a, A.A. Al-Fadhleeb and A.R. Khanc \\ *a Petrochemical Processes Program Element, Petroleum Research and Studies Center, Kuwait Institute for Scientific Research, \\ P.O. Box. 24885, Safat 13109, State of Kuwait \\ b Planning Department, International Marketing Sector, Kuwait Petroleum Corporation, P.O. Box. 26565, 13126, \\ Safat, State of Kuwait \\ c Department of Environmental Technology Management, College for Women, Kuwait University, P.O. Box. 5969, Safat 13060, \\ State of Kuwait
}

Received 27 September 2008; accepted 15 February 2009
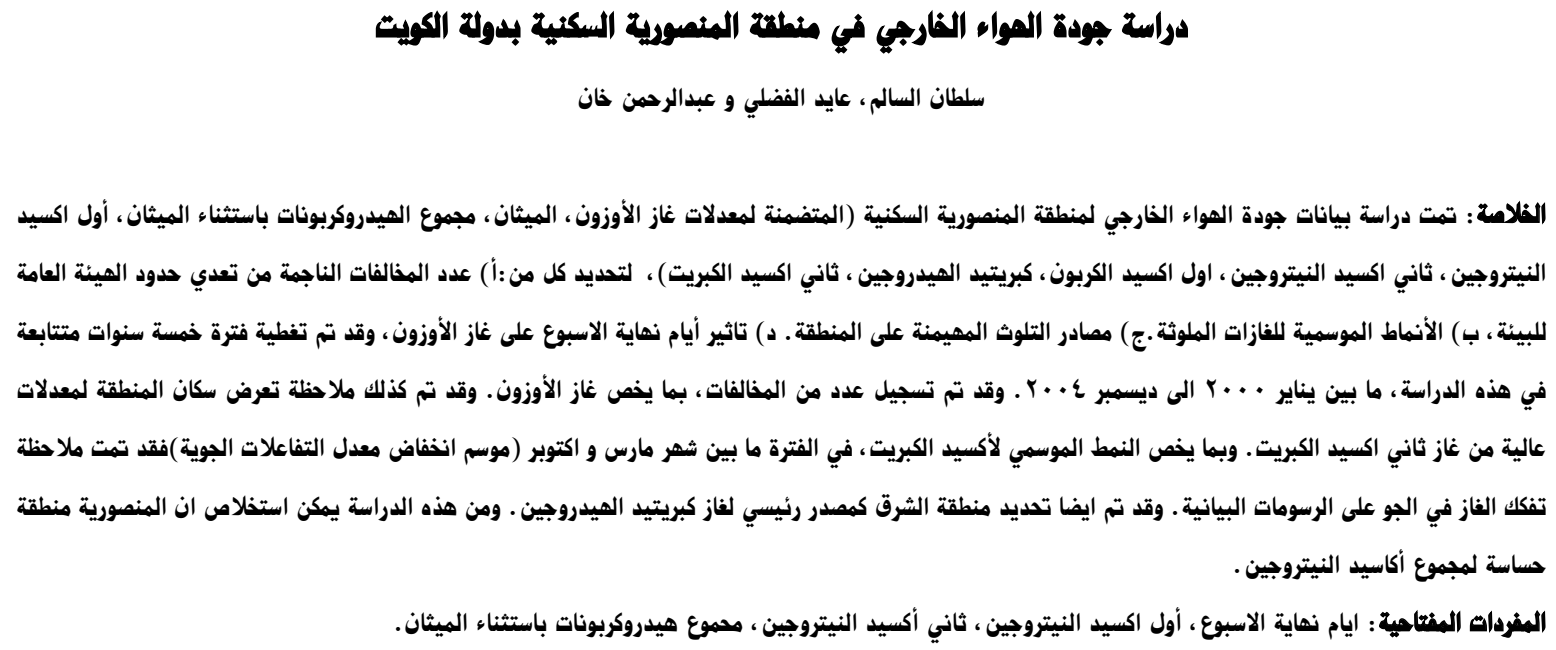

Abstract : Air quality data (ground level ozone $\left(\mathrm{O}_{3}\right)$, non-methane hydrocarbons (NMHC), methane $\left(\mathrm{CH}_{4}\right)$, nitrogen oxide (NO), nitrogen dioxide $\left(\mathrm{NO}_{2}\right)$, carbon monoxide $(\mathrm{CO})$, hydrogen sulfide $\left(\mathrm{H}_{2} \mathrm{~S}\right)$ and sulfur dioxide $\left(\mathrm{SO}_{2}\right)$ of a Kuwaiti residential area, Al-Mansoriah, were analyzed to evaluate and determine: (a) the exceedances of air quality from permissible limits set by the Kuwait Environment Public Authority (KUEPA), (b) the diurnal patterns of air pollutants, (c) the predominant sources of airborne pollutants in the surrounding area, and (d) the "weekend effect" on ozone levels. The dataset covered the period of five consecutive years, from January 2000 to December 2004. High levels of ozone were witnessed; recording a number of exceedances. Inhabitants of Al-Mansoriah were exposed, during the period of study, to acute and chronic levels of $\mathrm{SO}_{2}$. Concerning NMHC, the permissible limit ( $0.24 \mathrm{ppm}$ - rolling average between 6-9 am), was violated in each of the monitoring years. NO diurnal pattern showed two distinct strong peaks during the months from October to March, in which the low solar radiation does not cause intense photochemical reactions, which lead to NO destruction. A clear $\mathrm{H}_{2} \mathrm{~S}$ source (considered as a primary one) was witnessed from Kuwait city (Sharq district). The backed up sewage lines and maintenance work coinciding with study period clearly affected AlMansoriah. A clear "weekend effect", in terms of difference in levels occurring during midweek and weekends, was ascertained. The analysis suggests that Al-Mansoriah residential area should be considered a $\mathrm{NO}_{\mathrm{x}}$ sensitive region of Kuwait.

Keywords: Weekend effect, $\mathrm{NO}_{\mathrm{x}}, \mathrm{SO}_{2}, \mathrm{CO}, \mathrm{O}_{3}$, Monthly variation, Seasonal variation

\section{Introduction}

Since the autonomy of Kuwait Environment Public Authority (KUEPA) from the jurisdiction of the Ministry of Health (MOH) and the recognition of its legal holding power, pollution prevention in the state of Kuwait has

*Corresponding author’s e-mail: ssalem@ns1.prsc.kisr.edu.kw been of a growing concern over urban and suburban areas. Decision makers in the state express widespread interest in controlling greenhouse gases (GHGs), volatile organic compounds (VOCs) and other airborne pollutants. Increased levels of these pollutants, besides eroding materials, are known to have deleterious effects on human health (Brunekreef and Holgate, 2002, Al-Salem and Bouhamrah, 2006), to cause injury to plants (Saitanis et 
al. 200; Saitanis and Karandinos, 2002), to reduce crops yield (Nali et al. 2002) and to negatively affect ecosystems (Bytnerowicz et al. 2002). Natural ecosystems adjacent to urban areas are exposed increasingly to air pollutants of urban origin. Air pollutants, particularly $\mathrm{SO}_{2}, \mathrm{NO}_{2}$ and the major secondary photochemical oxidant $\mathrm{O}_{3}$ are important threats to plants. Their effects comprise many physiological and biochemical changes in plants, which may result in growth reduction and yield loss, even at low levels chronic exposure. Concerning human health, tropospheric $\mathrm{O}_{3}$ measured in urban regions and across regional airsheds, are known to affect human health (Riga-Karandinos and Saitanis, 2005).

Many researchers have been occupied with the great number of reactions and types of urban air pollutants (Wen and Lian, 2009; Fenger, 2009; Ramanathan and Feng, 2009; Gildemeister et al. 2007). One of the most important characteristics of urban air ph otochemistry is the oxidation of $\mathrm{SO}_{2}$ and $\mathrm{NO}_{2}$ and their conversion to particulate sulfate $\left(\mathrm{SO}_{4}^{2-}\right)$ and (gaseous and particulate) nitrates $\left(\mathrm{NO}_{3}\right)$. Moreover, the rate of the conversion of $\mathrm{NO}_{x}$ to $\mathrm{NO}_{3}$ affects ozone formation and the fate of the $\mathrm{NO}_{\mathrm{x}}$ in the atmosphere. $\mathrm{NO}_{\mathrm{x}}$ is oxidized to nitric acid $\left(\mathrm{HNO}_{3}\right)$ in the atmosphere, which in turn forms $\mathrm{NO}_{3}$ particles (Matsumoto and Tanaka, 1996). Acidification of precipitation, visibility reduction and deleterious effects on human health and plants, ar e all effects associated with these secondary pollutants. Such assessment of urban air quality will surely aid in the planning step of agencies concerned with green industries and keeping up with threshold and permissible limits in populated areas. Althou gh air quality was investigated in a number of urban areas in the state of Kuwait (Al -Salem and Khan, 2006; Al Salem et al. 2008a; Al-Salem et al. 2008b; Al-Salem et al. 2008c), there is insufficient or lack of information about the air pollution levels in many areas, which host a high percentage of the population of the country.

The objective of this work was to investigate the air pollution of a typical residential area in Kuwait, namely Al-Mansoriah. To this purpose we explored the air pollution levels in this area, with emphasis to ground level ozone $\left(\mathrm{O}_{3}\right)$, non-methane hydrocarbons (NMHC), methane $\left(\mathrm{CH}_{4}\right)$, nitrogen oxide (NO), nitrogen dioxide $\left(\mathrm{NO}_{2}\right)$, carbon monoxide $(\mathrm{CO})$, hydrogen sulfide $\left(\mathrm{H}_{2} \mathrm{~S}\right)$ and sulfur dioxide $\left(\mathrm{SO}_{2}\right)$. The exceedances of the air quality threshold values were calculated. The diurnal profiles and the seasonal variations of these gases are studied and the relationships between each other were explored. In addition, pollution sources in the surroundings of the area under investigation were identified using a series of concentration and wind roses analyses. The so called "weekend effect", concerning the variations of ozone levels between weekdays and weekends, was also investigated. the city which hosts mainly Kuwaiti residents of mid/high class (39,444 residents). Figure 1 shows the area from satellite imagery, relative to Kuwait city. Private and public transport vehicles reach a maximum of 45,000, mostly around the areas main streets.

The receptor (monitoring) point chosen for the area was above (at) the polyclinic of Al-Mansoriah situated near the area's Co-Op, which is associated with restaurants and other air polluting anthropogenic activities. These pollutants include $\mathrm{n}-\mathrm{CH}_{4}$ (resulting from restaurants), $\mathrm{NO}_{\mathrm{x}}$ and $\mathrm{CO}$ (emissions of automobile and other burning sources) and VOCs from the gas and gasoline dispensing station. On the other hand, Al-Arabi sports club is considered one of the largest sports and family functions facility in Kuwait, in terms of children entertainment lounges and other function spaces.

Cairo St. is situated to the north side of the receptor point. It is one of the busiest streets of Kuwait especially during rush hour, linking three main residential areas together in the governorate, ie. Al-Mansoriah, Al-Qadisiah and Al-Daeiah. Automobile vehicles operating with gasoline are the main source of pollution associated with traffic jam in the street. Rush hours are usually between 7:30 am to 9:00 am (weekdays); and 8:00 pm to 9:30 pm (weekends).

\section{Data Acquirement and Methods}

The dataset of Al-Mansoriah monitoring station, used in this study, was provided form the Kuwait Environment Public Authority (KUEPA). The data cover the period from Jan $1^{\text {st }} 2000$ to Dec 31 $1^{\text {st }}$ 2004. The station is equipped with a number of air sampling devices and analyzers (ThermoTecg 08, SatCal, Al-Issa Co. ltd.) with accuracy of order $1 \%$, with a measuring frequency of 5 minutes (original data). Air probe was approximately $15 \mathrm{~m}$ above sea level. All data were stored and manipulated with EnviDas data acquisition software, which did store up to three months worth of data values. Data collected by the station concerned the following pollutants: $\mathrm{CH}_{4}$ (ppm), NMHC (ppm), CO (ppm), NO (ppb), $\mathrm{NO}_{2}$ (ppb), H2S (ppb), $\mathrm{SO}_{2}$ (ppb), and $\mathrm{O}_{3}(\mathrm{ppb})$. Metrological conditions data were collected through a weather station recording the following parameters: wind speed $\left(\mathrm{ms}^{-1}\right)$ and direction ( ${ }^{\circ}$ ), relative humidity (\%) and ambient air temperature $\left({ }^{\circ} \mathrm{C}\right)$. Data points were treated and filtered before performing any analysis. Filtration procedure was performed as indicated by (Al-Salem and Khan, 2006). $\mathrm{NO}_{2}$ and $\mathrm{NO}$ values exceeding $200 \mathrm{ppb}$ were excluded, in order to eliminate any automobile point source effect on data collection. Values of $\mathrm{CH}_{4}$ levels below $1.3 \mathrm{ppm}$ were also removed to avoid insertion of instrumentation signal noise. Calibration and span check points were also deleted.

\section{Investigated Area Description}

Al-Mansoriah residential area is a luxurious suburb of 


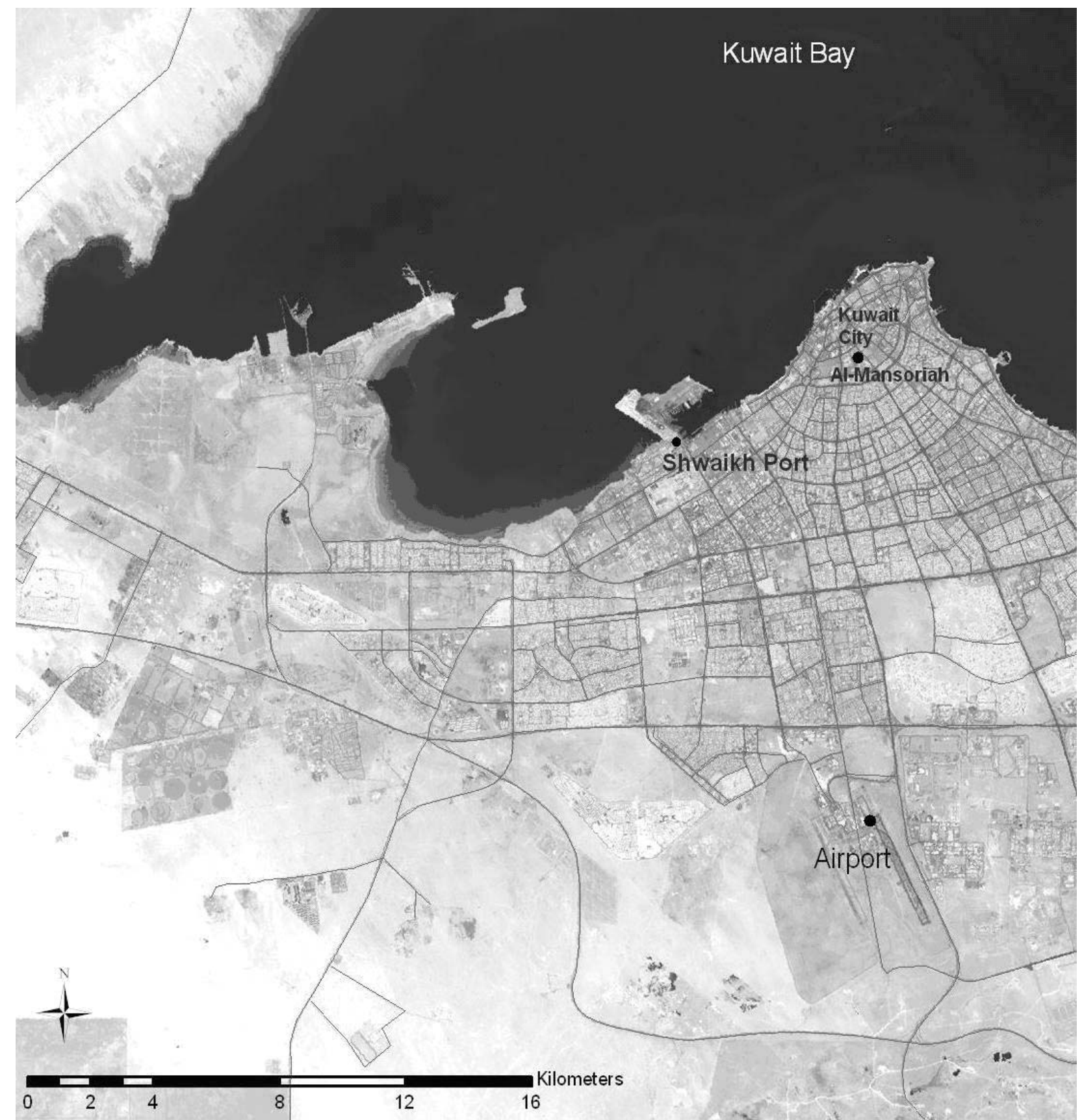

Figure 1. Al-Mansoriah residential area relative to Kuwait city. Image courtesy of satellite archieves, KGIC, Kuwait Institute for Scientific Research (KISR)

\section{Results and Discussions}

\subsection{Exceedances of Air Quality Permissible Limits/Threshold Values}

In order to assess the air quality in Al-Mansoriah area, measured levels of air pollutants were compared with threshold limits specified in the rules and regulations of Kuwait Environment Public Authority (KUEPA, 2001) and the European Directive standards (EEA, 2003a; EEA, 2003b). Concerning $\mathrm{O}_{3}$, for the protection of both, human health and ecosystem, KUEPA rules and regulations set a permissible limit of $80 \mathrm{ppb}$ as an hourly rolling (continu- ous) average for $\mathrm{O}_{3}$, not to be exceeded twice in a 30 days period. Inhabitants of Al-Mansoriah were exposed to $\mathrm{O}_{3}$ levels above the limit, but only a few days (Table 1 ). In 2000, six exceednaces were recorded based on 8-hrs rolling averages, and one in the year 2004 (Table 1). Judging from the current dataset of Al-Mansoriah, $\mathrm{O}_{3}$ levels should be considered potentially phytotoxic in this residential area. Investigations in other countries have shown that the nowadays ambient ozone levels can cause injury to plants. For example, (Saitanis et al. 2004) used plants of the ozone bioindicator Bel-W3 tobacco variety, at 28 sites around a town in Greece. In all those sites the used 
Table 1. Air quality data of Al-Mansoriah in comparison with the air quality rules and regulations determined by KUEPa (kuepsa, 2001)

$\begin{array}{cc}\text { Pollutant } & \text { Averaging period } \\ \text { Ozone } & 8 \mathrm{hrs}\end{array}$

Ozone Hourly

$\mathrm{NO}_{2}$

$\mathrm{NO}_{2}$

$\mathrm{NO}_{2}$

$\mathrm{SO}_{2}$

$\mathrm{SO}_{2}$

$\mathrm{SO}_{2}$

$\mathrm{CO}$

NMHC

Daily

Hourly

Annual

Hourly

Annual

Daily

Daily

6-9 am

\author{
Permissible limit \\ $60(\mathrm{ppb})$
}

bioindicator plants were highly injured even after one week of exposure. Similar studies, incorporating instrumental monitoring and phytodetection with ozonebioindicator plants, have demonstrated the occurrence of ozone at potentially phytotoxic levels in other rural and forest areas in Greece (Saitanis and Karandinos, 2001; Saitanis, 2003; Saitanis et al. 2003).

KUEPA has not yet established any long-term objectives for ozone levels in the near future (5-15 years). Long-term objectives have been established for Europe after considering the results of the scientific experiments conducted in the framework of the UN-ECE project over several years in many European countries (RigaKarandinos and Saitanis, 2005).

Current permissible limit in Europe, has been set to an AOT40 value of $3000 \mathrm{ppb}^{*} \mathrm{~h}$ above which direct adverse effects on trees, crops and natural vegetation may occur (Benton et al. 2000). AOT40 is the sum of the exceedances of the hourly ozone concentrations above the threshold of $40 \mathrm{ppb}$, during the daylight hours over a period of three months. The level of $40 \mathrm{ppb}\left(80 \mu \mathrm{g} / \mathrm{m}^{3}\right)$ of $\mathrm{O}^{3}$ should not be considered as a lower concentration limit in Europe for biological effects, since some biological $80(\mathrm{ppb})$

\#Exceedances/year

$6 / 2000$

$1 / 2004$

$6 / 2000$

$5 / 2001$

$1 / 2002$

$1 / 2003$

$3 / 2004$

$95 / 2000$

$48 / 2001$

$41 / 2002$

$93 / 2003$

$73 / 2004$

$234 / 2000$

$237 / 2001$

$342 / 2002$

$259 / 2003$

$323 / 2004$

30 (ppb)

$5 /(2000-2004)$

$5 / 2000$

$170(\mathrm{ppb}) \quad 8 / 2002$

$12 / 2003$

$17 / 2004$

$1 / 2003$

$5 / 2003$

$6 / 2004$

$120 / 2000$

$85 / 2001$

$178 / 2002$

$172 / 2003$

$207 / 2004$

responses may occur below that value (EEA, 2003a; EEA, 2003b). By comparison with other major European cities, Al-Manosriah exceeded the number of permissible limit exceedances ( $8 \mathrm{hr}$ rolling average) in the same duration of monitoring in Paris (Vardoulakis et al. 2002) and Aberdeen (Marr et al. 2007).

$\mathrm{SO}_{2}$ levels in Al-Mansoriah were generally high, which on the other hand, risks inhabitants of acute and chronic exposure to the pollutant. The KUEPA permissible limit (30 ppb) was violated in 2003 (annual threshold) and 5 exceedances were recorded in 2003 based on daily rolling averages. This also was typical of a Greek metropolis (Volos), were levels were monitored on the basis of a rolling average as well (Riga-Karandinos and Saitanis, 2005). It was also noticed that $\mathrm{SO}_{2}$ levels exceeded the European threshold limit for human protection reported previously (EAA, 2003a). Concerning $\mathrm{NO}_{2}, 279$ average exceedances per year were observed during the five years of monitoring for the short term (1 hr) limit. The corresponding annual permissible limit (30 ppb) was exceeded during the monitoring period (Table 1). For carbon monoxide (CO) the limit value (8000 ppb) of a daily mean was exceeded 6 times in 2004. 
Methane $\left(\mathrm{CH}_{4}\right)$ and non-methane hydrocarbons (NMHC) levels were monitored as well. KUEPA has not yet established any regulation for $\mathrm{CH}_{4}$ in Kuwait. It has, however, set a daily permissible limit $(0.24 \mathrm{ppm})$ for the period 6-9 am for NMHC. The analysis of data showed that NMHC recorded 153 exceedances (average) during the five years of monitoring. The number of exceedances increased gradually on an annual basis (Table 1).

\subsection{Diurnal Patterns of the Pollutants}

A good way of unraveling the dynamics and patterns of air pollutants is to examine their diurnal pattern. The average diurnal patterns of $\mathrm{O}_{3}, \mathrm{NMHC}, \mathrm{CH}_{4}, \mathrm{NO}, \mathrm{NO}_{2}$, $\mathrm{CO}, \mathrm{H}_{2} \mathrm{~S}$ and $\mathrm{SO}_{2}$ levels for each month of the year were examined (Fig. 2). Significant variations were observed between the pollutants studied in both, the recorded levels and diurnal patterns. It was observed that, in AlMansoriah residential area, $\mathrm{CO}, \mathrm{NO}$ and $\mathrm{NO}_{2}$, exhibit the typical urban daily pattern of primary air pollutants characterized by two peaks, one in the morning and one late in the evening (Riga-Karandinos and Saitanis, 2005). This pattern coincides with the human activities (traffic, open market hours and central heating). $\mathrm{SO}_{2}$ exhibited an unstable diurnal fluctuation. $\mathrm{SO}_{2}$ levels have been commented to be driven not only for the emissions but also from the levels of $\mathrm{O}_{3}$ and $\mathrm{OH}$ (Harrison and Perry, 1986) and the solar radiation (Riga-Karandinos and Saitanis, 2005). Khoder's (2002) results show that the oxidation processes and conversion of $\mathrm{SO}_{2}$ to sulfate and of $\mathrm{NO}_{2}$ to nitrate $\left(\mathrm{NO}_{3}\right)$ depend on the photochemical oxidation and that the sulfur conversion ratio increases with increasing ozone concentration.

The NO levels were higher during the months from October to March. During these months, the lower solar radiation intensity does not allow intense photochemical reactions (Riga-Karandinos and Saitanis, 2005), which would lead to NO destruction. The concentrations of NO, from April to September, were lower than during October to March months. However, during all, high and low NO months, the two typical peaks - one early in the morning and another in the evening - were present

The patterns of $\mathrm{O}_{3}$ show a clear seasonal and diurnal variation (increased ozone levels during months from April to September and a strong daytime photochemical ozone buildup due to photooxidation of precursor gasses) showing more intense photochemical processes during the luminous hours of the days and during the high sunlight season (Fig. 2). According to (Simpson et al. 1995), annual cycle of ozone over mid-latitudes shows mainly two kinds of seasonal behavior, either with a broad summer maximum, generally attributed to local photochemical productions and typical of populated and industrialized areas, or with a spring maximum, of more controversial origin, typical of remote regions and associated to background conditions. The high rush-hour traffic during early morning between 7:30 am to 9:00 am (weekdays); and 8:00 pm to 9:30 pm (weekends), well before sun radiation is strong enough to trigger photochemical reactions of ozone formation leads to ozone destruction shown in Fig. 2 as ozone decrease.

The witnessed patterns of CO were, somewhat, inverse to those of ozone. It was clear that seasonal variations of ozone affected indirectly the seasonal pattern of CO. Ozone is the photochemical precursor of hydroxyl radicals $(\mathrm{OH})$ in the lower troposphere. Reaction with $\mathrm{OH}$ removes most gases of natural and anthropogenic origin from the atmosphere (Jockel et al. 2003). It is also a fact that the main mechanism for the removal of $\mathrm{CO}$ from the atmosphere is the reaction of $\mathrm{OH}$. On the other hand, tropospheric oxidation reactions of $\mathrm{CO}$ in the presence of sufficient NO also lead to the production of substantial amounts of ozone. The comparison of the diurnal patterns of $\mathrm{O}_{3}$ and $\mathrm{CO}$, suggests that the depletion of $\mathrm{O}_{3}$ and the enhancement of $\mathrm{CO}$, during the non-photochemistry hours (early morning and late in the evening), come from the $\mathrm{O}_{3}$ titration when mixed with urban emissions and simultaneously the anthropogenic release of CO. This pattern of CO may be the typical signature of urban influence (Fig. 2).

Regarding $\mathrm{CH}_{4}$ patterns, a clear increase was witnessed in the early morning hours (5-7 am) associated with restaurants and other gas operated businesses opening hours. The same is clear for non-methane hydrocarbons (NMHC). The levels increase for both pollutants and reach their peak in the three summer break months, ie. July, August and September. This could be attributed to the increasing activities in luxurious areas like AlMansoriah in the summer time.

\subsection{Wind and Pollutants' Concentrations Roses}

In order to investigate the predominant sources affecting Al-Mansoriah residential area, five years mean wind rose and concentration roses for the air pollutants $\left(\mathrm{O}_{3}\right.$, NMHC, $\mathrm{CH}_{4}, \mathrm{NO}, \mathrm{NO}_{2}, \mathrm{CO}, \mathrm{H}_{2} \mathrm{~S}$ and $\mathrm{SO}_{2}$ ), around the receptor point, (Al-Mansoriah polyclinic) were analyzed. Kuwait is characterized by north/northwestern winds (primary direction) contributing to over $70 \%$ of the winds around the year (Khan and Al-Salem, 2007). Figure 3 shows the $15^{0}$ wind speed rose executed for the period of study around Al-Mansoriah. West/west-northern and north/northwestern winds covering the corridor of wind direction between 285-3300, establish the primary wind direction with average winds exceeding $6 \mathrm{~ms}^{-1}$. All wind and pollutants' concentrations' roses in this study are in a blowing form manner.

Southeastern winds could be considered as secondary winds ( $6 \mathrm{~ms}^{-1}$ ) in the case of Al-Mansoriah residential area, as well as the state of Kuwait over the past 30 years (Al-Hajraf et al. 2005).

In the case of $\mathrm{H}_{2} \mathrm{~S}$, the concentration rose reveals a spike value (3450- exceeding $5 \mathrm{ppb}$ ) in the direction of Sharq district in Kuwait city (Fig. 4). Backed up sewage and municipal work has been commenced in the period of study in which pedestrians in the district use to complain 


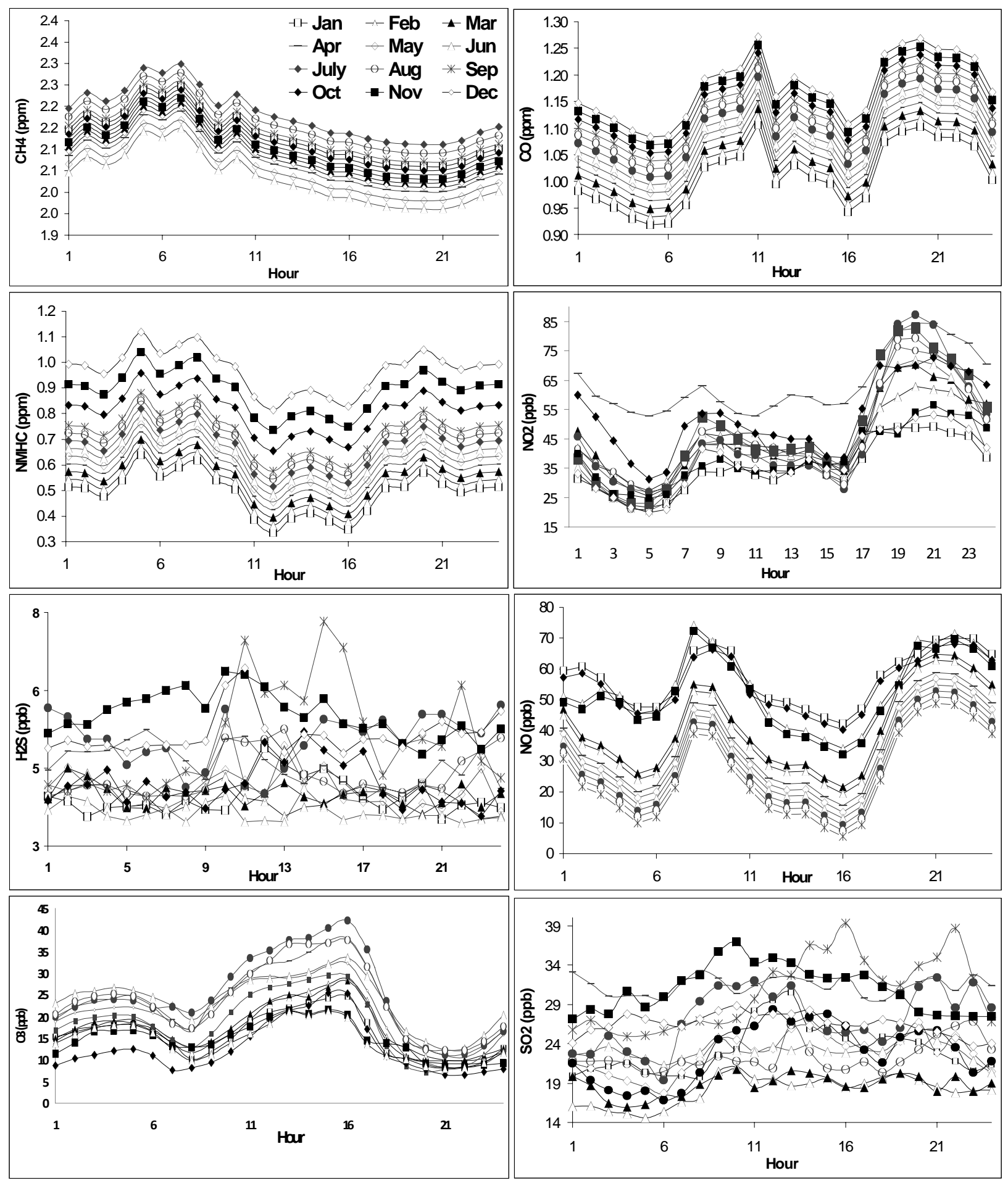

Figure 2. Plots of monthly diurnal patterns of air pollutants in Al-Mansoriah

for suffering rotten eggs odor (typical of $\mathrm{H}_{2} \mathrm{~S}$ vented or other type of emissions from municipal manholes) in Sharq. Other directions on the concentration rose show similar emission strength from wind corridors, which are typical for urban and suburban areas (Khan and Al-Salem, 2007).

Methane gas followed typical behavior in almost every case (excluding industrial sites), being uniform from all wind directions (Fig. 5). $\mathrm{CH}_{4}$ averaged at $2 \mathrm{ppm}$, which is also typical of Kuwaiti urban areas as previously reported in Fahaheel (Al-Salem and Khan, 2006; Al-Salem et al. 2008a) and Al-Riqa (Al-Salem et al. 2008b; Al-Salem et al. 2008c; Al-Salem and Al-Fadhlee, 2008). CO also showed typical urban behavior and concentration rose trend; being uniform around the receptor point and averaging about $1 \mathrm{ppm}$ (Fig. 5). Daily activities in AlMansoriah contribute greatly to both $\mathrm{CH}_{4}$ and $\mathrm{CO}$ concentration roses. Automobile emissions, dry cleaning services, gas dispensing networks and restaurant emissions; all contribute to both pollutants. Sources of these emissions 


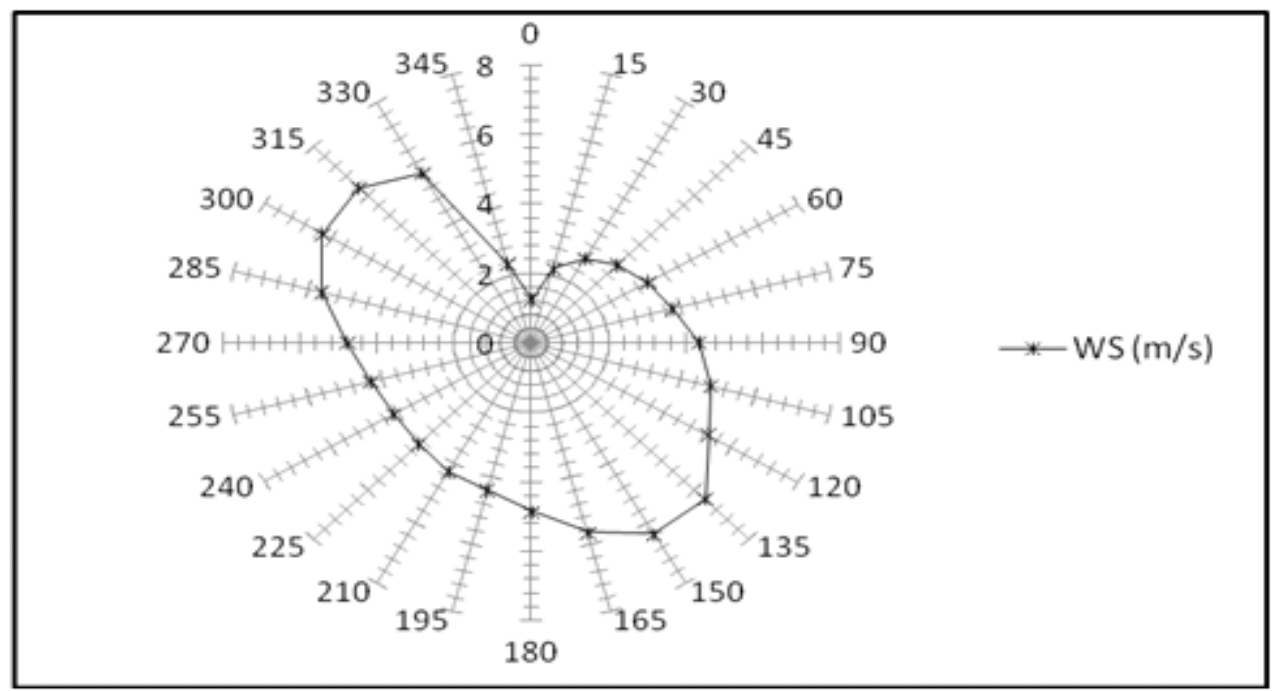

Figure 3. Plot (rose) of the average wind speed $\left(\mathrm{ms}^{-1}\right)$ monitored in Al-Mansoriah during the period (January 2000 to December 2004)

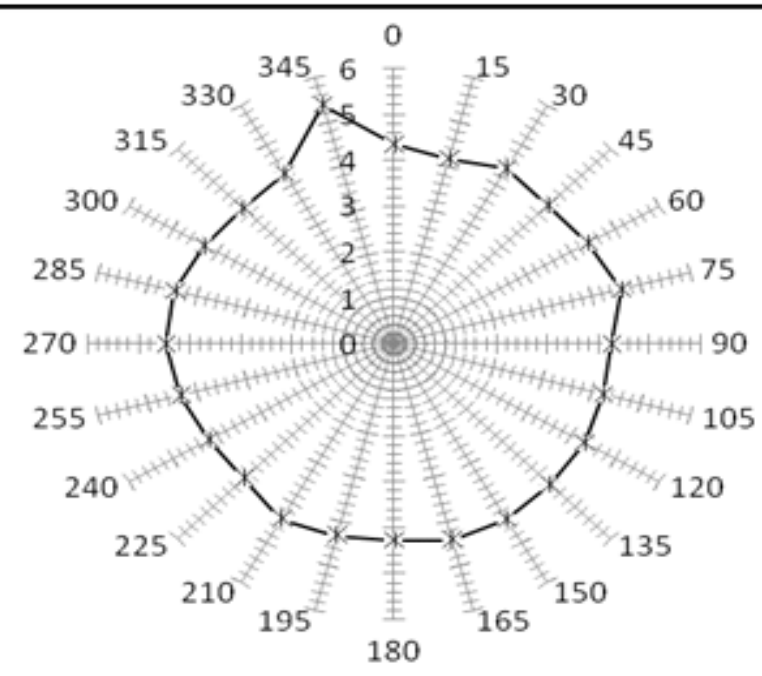

$-*-\mathrm{H} 2 \mathrm{~S}(\mathrm{ppb})$

Figure 4. Plot (rose) of the average $\mathrm{H}_{2} \mathrm{~S}$ (ppb) monitored in Al-Mansoriah during the period (from January 2000 to December 2004)

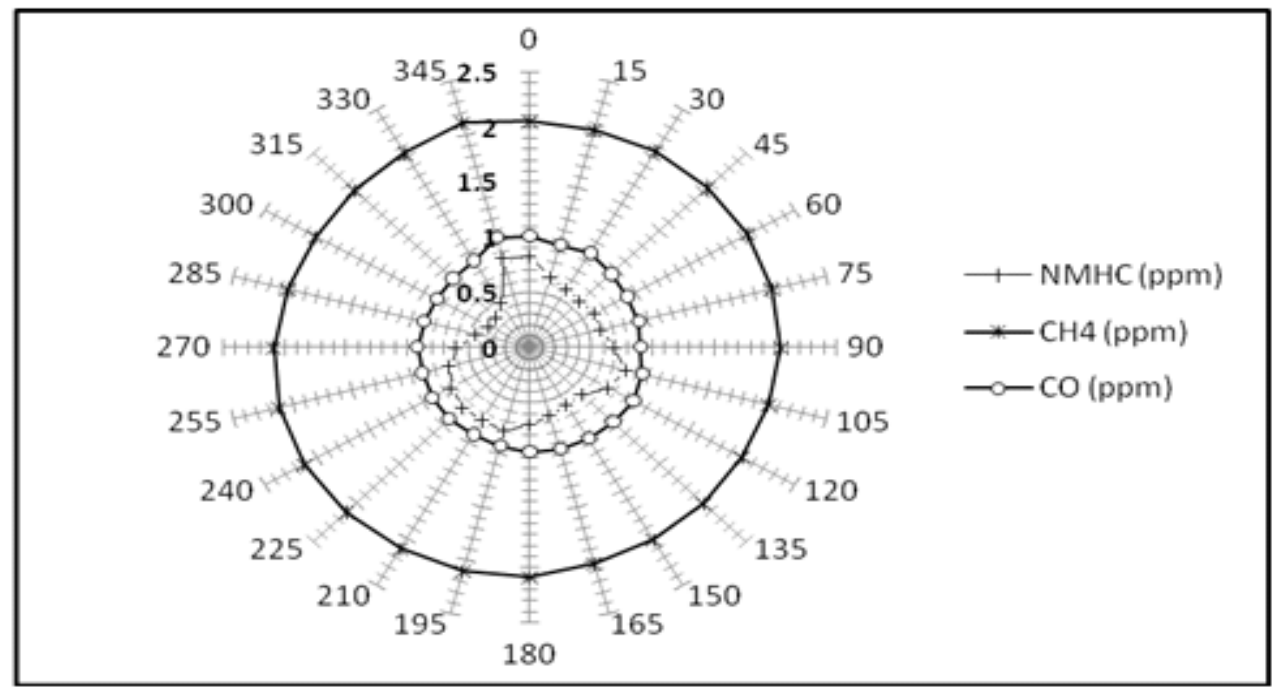

Figure 5. Plot (rose) of average $\mathrm{CH}_{4}$, NMHC and $\mathrm{CO}$ concentration rose (ppm) monitored in Al-Mansoriah during the period (from January 2000 to December 2004) 
are distributed around the receptor point, which explains the trends left by both $\mathrm{CH}_{4}$ and $\mathrm{CO}$ on the roses. Regarding NMHC, the concentration rose shows a peak in the emission strength in the northwestern direction (Fig. 5).

Figure 6 shows the concentration rose for $\mathrm{NO}$ and $\mathrm{NO}_{2}$ gases around the receptor point. Northern winds (covering 345-150) were clearly the richest in both pollutants (exceeding $60 \mathrm{ppb}$ for $\mathrm{NO}_{2}$ and $70 \mathrm{ppb}$ for NO). This direction corresponds to Kuwait city, which hosts a number of combustion sources that contribute to $\mathrm{NO}$ and $\mathrm{NO}_{2}$ levels in the ambient.

Opposite to $\mathrm{NO}_{\mathrm{x}}$, winds blowing from northwestern and eastern directions showed higher ozone levels (Fig. 7). $\mathrm{NO}_{\mathrm{x}}$ titration and other sets of reactions fade ozone from the lower atmosphere, which also explains the NO primary direction of north. $\mathrm{SO}_{2}$ was present around the receptor point in an almost equal level of 25 ppb (Fig. 8).

\subsection{Weekend/ Weekday Variations}

During the past decade, weekend/weekday differences in levels of air pollutants (especially of $\mathrm{O}_{3}$ ) have been a subject of research interest (Marr and Harley, 2002; Vandaele et al. 2002; Fujita et al. 2003, Riga-Karandinos and Saitanis, 2005). Although, weekly changes in the emissions caused by human activities are known to affect the weekly cycle of ambient pollutant concentrations, this emission-concentration relationship, in urban, suburban and rural sites, is not well elucidated as it is reflected in controversial reports (Blier and Winer, 1999; Pun et al. 2003). In the state of Kuwait, during the period of the study, the weekend was on Thursdays and Fridays (nowadays the weekend has shift to Fridays and Saturdays).

In weekends (Thursdays and Fridays), the emissions of anthropogenic pollutants and especially of $\mathrm{O}_{3}$ precursors, are believed to be lower compared to those occurring during weekdays, because car traffic is lower and several polluting plants and factories may be less active or inactive. Many approaches have been used for the study of the socalled weekend effect, meaning the occurrence of increased $\mathrm{O}_{3}$ levels and decreased $\mathrm{NO}_{\mathrm{x}}$ during weekends in comparison to weekdays. Near constant $\mathrm{O}_{3}$ levels, during weekdays, in the face of strong weekday/weekend variations in $\mathrm{NO}_{\mathrm{x}}$, should also be viewed as a weekend effect (Fujita et al. 2003).

After taking into account the shift in the relaxing days and the days of high anthropogenic activities in Kuwait, in comparison to the west countries, in this study, we analyzed the monthly averages of mean hourly $\mathrm{O}_{3}$ and NO concentrations during Sunday-Tuesday vs. the corresponding concentrations on Wednesday, Thursday, Friday and Saturday, recorded in Al-Mansoriah, (Fig. 9). In Table 2, the relevant linear regression equations and the corresponding correlation coefficients are given.
Concerning $\mathrm{O}_{3}$, the slops of linear regressions revealed that Wednesday concentrations were very close to those occurring in during Sun-Tue (Fig. 9; Table 2). Unexpectedly, Thursdays-Saturdays $\mathrm{O}_{3}$ concentrations were much lower than Sun-Tue concentrations. Regarding NO, during Wednesdays and Thursday the slops were clearly close to one indicating similar levels occurring during these two days to those occurring during Sun-Tue. On the other hand, NO levels were clearly much lower on Fridays than ones occurring during Sun-Tue (Fig. 9; Table 2). Elevated $\mathrm{NO}_{\mathrm{x}}$ levels can always inhibit $\mathrm{O}_{3}$ production either by $\mathrm{NO}$ titration of $\mathrm{O}_{3}$ or by reaction of $\mathrm{NO}_{2}$ and $\mathrm{OH}$ to form $\mathrm{HNO}_{3}$-nitric acid- (Riga-Karandinos and Saitanis, 2005). Synoptically, $\mathrm{O}_{3}$ decreases more rapidly with reductions in NOx emissions, than with reductions in VOCs (Volatile Organic Compounds) in $\mathrm{NO}_{\mathrm{x}}$-sensitive regions (ie. abundant VOCs relative to $\mathrm{NO}_{\mathrm{x}}$ ). While in VOCs-sensitive regions (ie. abundant NOx relative to VOCs) a decrease in $\mathrm{NO}_{\mathrm{x}}$ emissions may cause an increase in $\mathrm{O}_{3}$ because of reduced titration or reduced formation of $\mathrm{HNO}_{3}$. Locations where ozone increases during weekends, while $\mathrm{NO}_{\mathrm{x}}$ emissions are significantly lower should be considered VOCs-limited (Blanchard and Tanenbaum, 2003). Thus, in the case of Al-Mansoriah residential area, signs of being a $\mathrm{NO}_{\mathrm{x}}$ sensitive region are very clear although $\mathrm{NO}_{\mathrm{x}}$ levels are not always higher on weekends, suggesting a strongly influential background effect.

The reduction of anthropogenic emissions during weekends is expected to reduce proportionally equally anthropogenic VOCs (AVOCs) and $\mathrm{NO}_{\mathrm{x}}$. In addition to the above-discussed role of VOCs in the "weekend effect", it is the high early morning rush-hour traffic on weekends that allow ozone concentrations to rise from a significantly lower concentration and therefore reaching lower overall weekend concentrations.

A number of studies demonstrate a wide range in the weekday/weekend $\mathrm{O}_{3}$ behavior. Marr and Harley (2002) suggest that $\mathrm{NO}_{\mathrm{x}}$ concentrations are consistently lower on weekends relative to weekdays by approximately 30-40\%, while VOC changes are less pronounced (approximately 10\%). The explanation of weekday/weekend variation, due to $\mathrm{NO}$ x reduction, is supported by a wide range of analyses of ambient data and several photochemical studies, while changes in the timing and location of emissions and meteorological factors play smaller roles in weekend $\mathrm{O}_{3}$ behavior (Heuss et al. 2003; Riga-Karandinos and Saitanis, 2005). Analyses of ambient air quality data and emissions forecasts for weekdays and weekends may improve considerably our understanding of the effects of control strategi es and of future changes in emissions on future ambient $\mathrm{O}_{3}$ concentrations. 


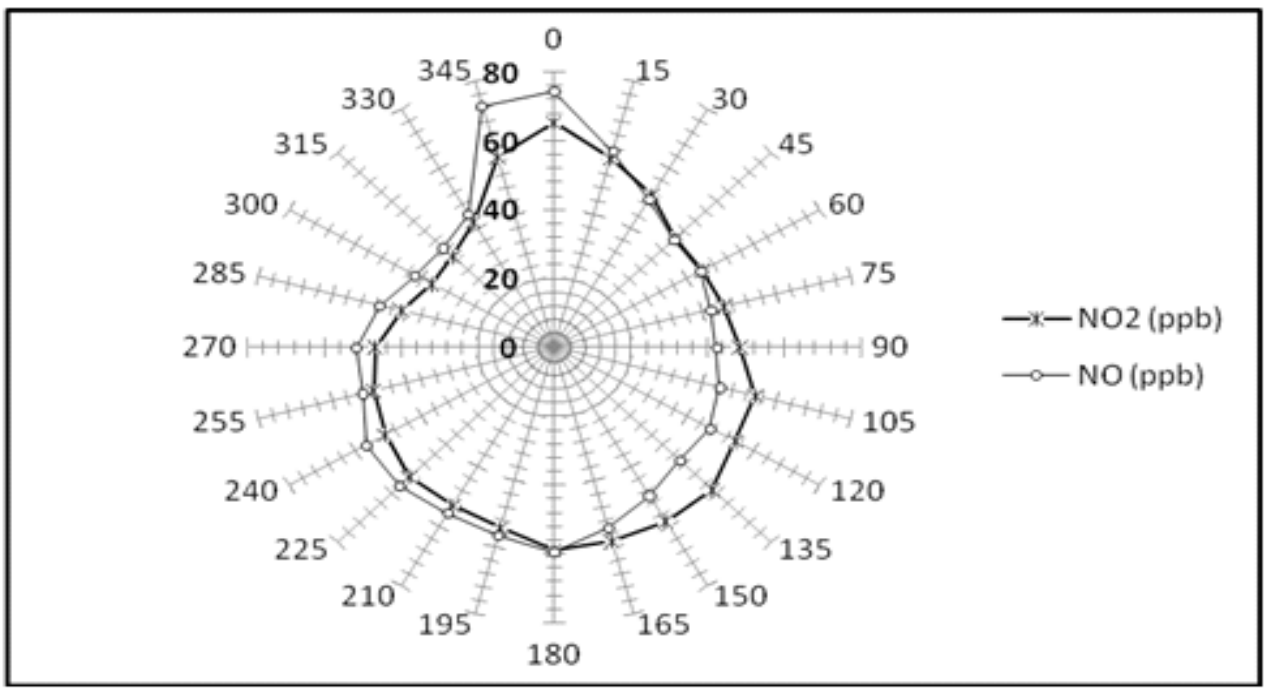

Figure 6. Plot (rose) of average $\mathrm{NO}$ and $\mathrm{NO}_{2}$ concentration rose (ppb) monitored in Al-Mansoriah during the the period (from January 2000 to December 2004)

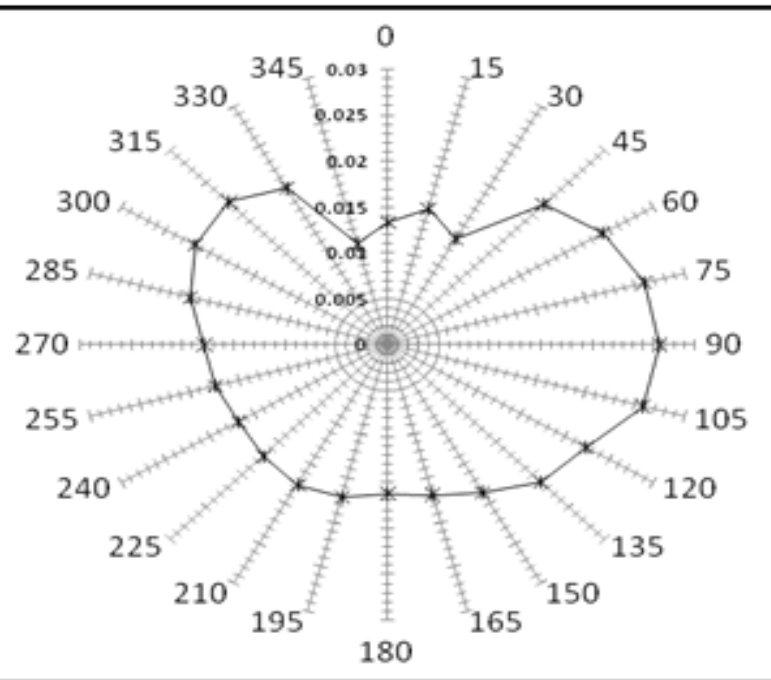

Figure 7. Plot (rose) of average $\mathrm{O}_{3}$ concentration rose (ppb) monitored in Al-Mansoriah during the period (from January 2000 to December 2004)

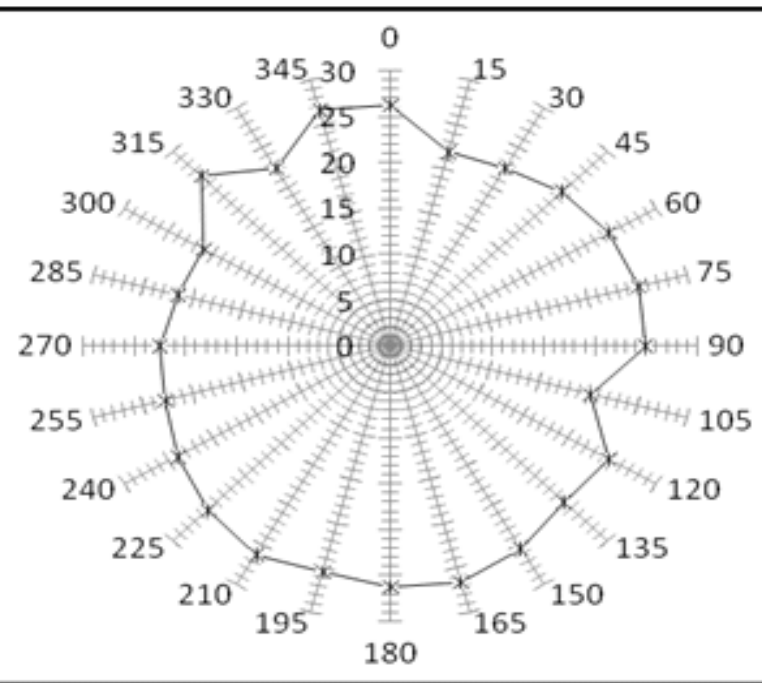

Figure 8. Plot (rose) of average $\mathrm{O}_{3}$ concentration rose (ppb) monitored in Al-Mansoriah during the period (from January 2000 to December 2004) 

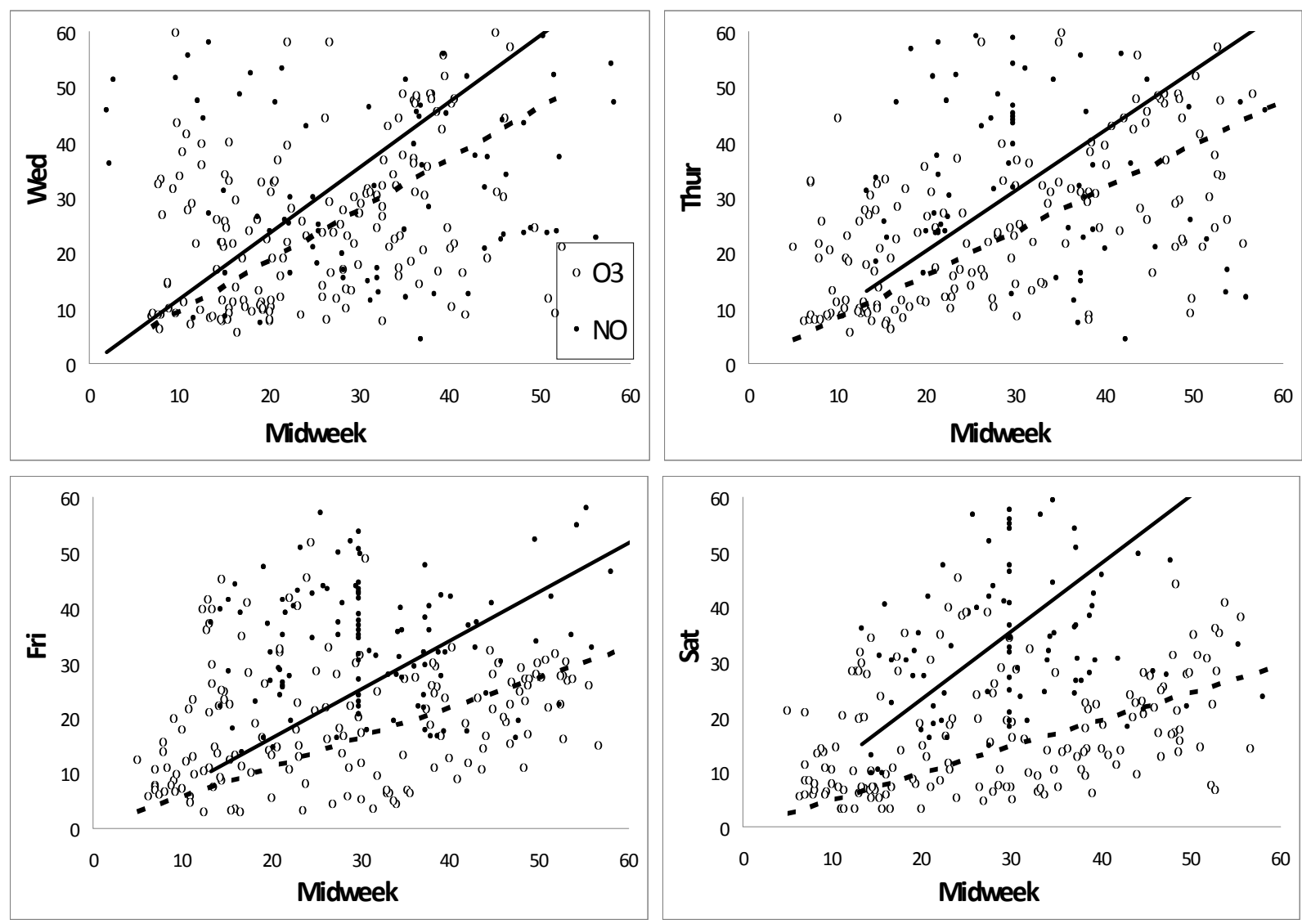

Figure 9. Regression plots of the monthly averages of the mean hourly ozone (dashed line) and NO (solid line) concentrations during midweek (Sun-Tues) vs. the corresponding concentrations of the rest of the week

Table 2. Regression equations of mean hourly ozone concentrations during (Sun-Tues) vs. the corresponding mean hourly ozone concentratopns on Wednesday, Thursday, Friday, and Saturday (X)

Day/

(Pollutant)

Wednesday/ $\mathrm{O}_{3}$

Wednesday/ NO

$Y=0.91 X$

$Y=1.02 X$

$r=0.28$

Thursday/ $\mathrm{O}_{3}$

Thursday/ NO

Friday/ $\mathrm{O}_{3}$

Friday/ NO

Saturday/ $\mathrm{O}_{3}$

Saturday/ NO

$Y=0.78 X$

$r=0.24$

$Y=0.97 X$

$r=0.40$

$Y=0.54 X$

$\mathrm{r}=0.87$

$Y=0.77 X$

$r=0.64$

$Y=0.48 X$

$r=0.67$

$Y=1.12 X$

$r=0.46$

$r=0.54$

\section{Conclusions}

After analyzing the dataset obtained for Al-Mansoriah residential area, a number of exceedances were recorded, violating KUEPA permissible limits of air quality. Concerning the exceedances of $\mathrm{O}_{3}$, there were no exceedances violating annual or daily limits. However, inhabitants of Al-Mansoriah were exposed to acute $\mathrm{SO}_{2}$ levels. Recorded $\mathrm{NO}_{2}$ annual, daily and hourly

exceedances in the five years of monitoring. The diurnal patterns of the studied pollutants were investigated and revealed a seasonal variation in ozone levels. An inverse pattern was witnessed for CO. On the other hand, methane patterns showed an increase in the early morning hours associated with the anthropogenic activates in the area.

Series of concentration roses were executed around the receptor point (ie. polyclinic) to determine the influential pollution sources around Al-Mansoriah. Methane and CO showed typical urban area patterns, while $\mathrm{NO}$ and $\mathrm{NO}_{2}$ concentration roses revealed a primary source situated in northern wind corridor (covering 345-150). Weekend effect analysis revealed that the area under investigation was a $\mathrm{NO}_{\mathrm{x}}$ sensitive one. The causes of the weekend $\mathrm{O}_{3}$ effect are probably the weekend/weekday differences in $\mathrm{NO}_{\mathrm{x}}$ emissions and the complex non-linear photochemistry of ozone. The data of this study would be useful for future comparisons, after the operation of the new infrastructures at Kuwait city (Sharq district), which certainly will cause changes in pollutants levels. It is obvious that, for future air quality management strategies, the development of accurate, temporally and spatially resolved dayof-week emission inventories, including separate inventories for weekends can promote a better understanding. 


\section{References}

Al-Hajraf, S., Al-Ajmi, D., Khan, A., Tang, H., Wahner, A. and Klemp, D., 2005, "Air Quality Assessment of Ali Sabah Al-Salem Urban Community," KISR final report \#EC031C.

Al-Salem, S.M. and Al-Fadhlee, A.A., 2008, "Source Identification of Selected Airborne Pollutants using Concentration and Wind Roses Simulated around AlAhmadi Governorate in the State of Kuwait," In: Proc 3rd International Conference on Scientific Computing to Computational Engineering (3rd IC-SCCE), Athens, Greece.

Al-Salem, S.M. and Bouhamrah, W.S., 2006, "Ambient Concentrations of Benzene and other VOC's at Typical Industrial Sites in Kuwait and their Cancer Risk Assessment," Research Journal of Chemistry and Environment, Vol. 10(3), pp. 42-46.

Al-Salem, S.M. and Khan, A.R., 2006, "Methane Dispersion Modeling and Source Determination around Urban Areas in Kuwait," In: Proc 1st International Conference \& Exhibition on Green Industry, Manama, Bahrain.

Al-Salem, S.M., Al-Fadhlee, A.A. and Al-Haddad, A.A., 2008b, "Monitoring Hydrocarbons Levels in Al-Riqa Urban Area (Kuwait) using Modern Environmental Techniques: Investigating the Effect of Petroleum Downstream Industries on the Outdoor Air Quality," In: Proc (RecShow '08) Middle East Recycling, Waste and Environmental Management Exhibition \& Congress, Dead Sea, Jordan, 17th-20th February, pp. 48.

Al-Salem, S.M., Al-Fadhlee, A.A., Al-Haddad, A.A. and Khan, A.R., 2008c, "Identifying the Contribution of Air Pollution Sources in Al-Riqa Urban Area (Kuwait) using Chemical Mass Balance (CMB) Modeling," In: Proc Climate Change, Energy and Environ Management Conference, Johannesburg, South Africa, 23rd-25th March.

Al-Salem, S.M., Al-Haddad, A.A. and Khan, A.R., 2008a, "Primary Pollutants Monitoring and Modeling using Chemical Mass Balance (CMB) around Fahaheel Residential Area," American Journal of Environmental Sciences, Vol. 4(1), pp. 13-21.

Benton, J., Fuhrer, J., Gimeno, B.S., Skarby, L., PalmerBrown, D., Ball, G., Roadknight, C. and Mills, G., 2000, "An International Cooperative Programme indicates the Widespread Occurrence of Ozone Injury on Crops," Agriculture, Ecosystems and Environment, Vol. 78(1), pp. 19-30.

Blanchard, C.L. and Tanenbaum, S.J., 2003, "Differences between Weekday and Weekend Air Pollutant Levels in Southern California," Journal of Air \& Waste Manage Association, Vol. 53(3), pp. 816-828.

Blier, W. and Winer, A.M., 1999, "Analysis of Weekday/Weekend differences in Ambient Air Quality and Meteorology in the South Coast Air
Basin," Final Report; Contract No. 95-334. California Air Resources Board, Sacramento, CA.

Brunekreef, B. and Holgate, S.T., 2002, "Air Pollution and Health", Lancet, Vol. 360(9341), pp. 1233-1242.

Bytnerowicz, A., Godzik, B., Fraczek, W., Grodzinska, K., Krywult, M., Badea, O., Barancok, P., Blum, O., Cerny, Godzik, M., Mankovska, S., Manning, B., Moravcik, W., Musselman, P., Oszlanyi, R., Postelnicu, J., Szdzuj, D., Varsavova, J. and Zota, M., 2002, "Distribution of Ozone and other Air Pollutants in Forests of the Carpathian Mountains in central Europe," Environment Pollution, Vol. 116(1), pp. 3-25.

EEA, 2003a, "Exposure of Population to Exceedances of EU Air Quality Standards (2002)," Available online (June 2004).

EEA, 2003b, "Air Pollution by Ozone in Europe in Summer 2003-Overview Exceedances of EC Ozone Threshold Values during the Summer April-EU 1999," Council Directive 1999/30/EC of 22 April 1999 relating to limit values for sulphur dioxide, nitrogen dioxide and oxides of nitrogen, particulate matter and lead in ambient air, Official Journal of the European Communities 29.6.1999, L 163/41.

Fenger, J., 2009, "Air Pollution in the Last 50 Years From Local to Global," Atmospheric Environment, Vol. 43(1), pp. 13-22.

Fujita, E.M., Stockwell, W.R., Campbell, D.E., Keislar, R.E. and Lawson, D.R., 2003, "Evolution of the Magnitude and Spatial Extend of the Weekend Ozone Effect in California South Coast Air Basin, 19812000," Journal of Air \& Waste Manage Association, Vol. 53, pp. 802-815.

Gildemeister, A.E., Hopke, P.K. and Kim, E., 2007, "Sources of Fine Urban Particulate Matter in Detroit, MI," Chemosphere, Vol. 69(7): 1064-1074.

Harrison, R.M. and Perry, R., 1986, "Handbook of Air Pollution Analysis," second ed. Chapman and Hall, London, New York.

Heuss, J.M., Kahlbaum, D.F. and Wolff, G.T., 2003, "Weekday/Weekend Ozone differences: What can we learn from them," Journal of Air \& Waste Manage Association, Vol. 53(4), pp. 772-788.

Jockel, P., Brenninkmeijer, C.A.M. and Crutzen, P.J., 2003, "A Discussion on the Determination of Atmospheric $\mathrm{OH}$ and its Trends," Atmospheric Chemistry \& Physics, Vol. 3(2), pp. 107-118.

Khan, A. and Al-Salem, S., 2007, "Seasonal Variation Effect on Airborne Pollutants in an Urban Area of the State of Kuwait," Journal of Environmental Research \& Development, Vol. 1(3), pp. 215-218.

Khoder, M.I., 2002, "Atmospheric Conversion of Sulfur Dioxide to particulate Sulfate and Nitrogen Dioxide to Particulate Nitrate and Gaseous Nitric Acid in an Urban Area," Chemosphere, Vol. 49(6), pp. 675-684.

KUEPA Rules \& Regulations, 2001, "Kuwait Al-Youm Appendix 533," KWT Gov. Press, law 210/2001. 
Marr, I.L., Rosser, D.P. and Meneses, C.A., 2007, "An Air Quality Survey and Emissions Inventory at Aberdeen Harbour," Atmospheric Environment, Vol. 41 (1), pp. 6379-6395.

Marr, L. and Harley, R.A., 2002, "Spectral Analysis of Weekday- Weekend differences in Ambient Ozone, Nitrogen Oxide and Non-Methane Hydrocarbons Time Series in California," Atmospheric Environment, Vol. 36(14), pp. 2327-2385.

Matsumoto, K. and Tanaka, H., 1996, "Formation and Dissociation of Atmospheric Particulate Nitrate and Chloride: an Approach Based on Phase Equilibrium," Atmospheric Environment, Vol. 30(4), pp. 639-648.

Nali, C., Pucciariello, C. and Lorenzini, G., 2002, "Ozone Distribution in Central Italy and its Effects on Crops Productivity," Agriculture, Ecosystems and Environment, Vol. 90(3), pp. 277-289.

Pun, B.K., Seigneur, Ch. and White, W., 2003, "Day-ofWeek Behavior of Atmospheric Ozone in Three US Cities," Journal of Air \& Waste Manage Association, Vol. 53(3), pp. 789-801.

Ramanathan, V. and Feng, Y., 2009, "Air Pollution, Greenhouse Gases and Climate Change: Global and Regional Perspectives," Atmospheric Environment, Vol. 43(1): 37-50.

Riga-Karandinos, A.N. and Saitanis, C., 2005, "Comparative Assessment of Ambient Air Quality in Two Typical Mediterranean Coastal Cities in Greece," Chemosphere, Vol. 59(8), pp. 1125-1136.

Saitanis, C.J. and Karandinos, M.G., 2001, "Instrumental Recording and Biomonitoring of Ambient Ozone in Greek Countryside", Chemosphere, Vol. 44(4), pp. 813-821.

Saitanis, C.J. and Karandinos, M.G., 2002, "Effects of Ozone on Tobacco (Nicotiana tabacum L.) Varieties," Journal of Agronomy and Crop Science, Vol. 188(1), pp. 51-58.
Saitanis, C.J., 2003, "Background Ozone Levels Monitoring and Phytodetection in the Greater Rural Area of Corinth-Greece," Chemosphere, Vol. 51(5), pp. 913-923.

Saitanis, C.J., Karandinos, M.G., Riga-Karandinos, A.N., Lorenzini, G. and Vlassi, A., 2003, "Photochemical Air Pollutant Levels and Ozone Phytotoxicity in the Region of Mesogia-Attica," Greece, International Journal of Environmental Pollution, Vol. 19(2), pp. 197-208.

Saitanis, C.J., Katsaras, D.H., Riga-Karandinos, A.N., Lekkas, D.B. and Arapis, G., 2004, "Evaluation of Ozone Phytotoxicity in the Greater Area of a Typical Mediterranean Small City (Volos) and in the nearby Forest (Pelion Mt.)-Central Greece," Bulletin of Environmental Contamination and Toxicology, Vol. 72(6), pp. 1268-1277.

Saitanis, C.J., Riga-Karandinos, A.N. and Karandinos, M.G., 2001, "Effects of Ozone on Chlorophyll and Quantum yield of Tobacco (Nicotiana tabacum L.) Varieties," Chemosphere, Vol. 42(17), pp. 945-953.

Simpson, O., Guenter, A., Hewitt, C.N. and Steinbrecher, R., 1995, "Biogenic Emissions in Europe I: Estimates and Uncertainties," Journal of Geophysical Research, Vol. 100(D11), pp. 22875-22890.

Vandaele, A.C., Tsouli, A., Carleer, M. and Colin, R., 2002, "UV Fourier Transform Measurements of Tropospheric O3, NO2, SO2, Benzene and Toluene," Environmental Pollution, Vol. 116(12), pp. 193-201.

Vardoulakisa, S., Gonzalez-Flescaa, N. and Fisher, B.E.A., 2002, "Assessment of Traffic-Related Air Pollution in Two Street Canyons in Paris: Implications for Exposure Studies," Atmospheric Environment, Vol. 36(1), pp. 1025-1039.

Wen, Y. and Lian, Z., 2009, "Influence of Air Conditioners Utilization on Urban Thermal Environment," Applied Thermal Engineering, Vol. 29(4), pp. 670-675. 